\title{
Acquisition of family farm foods in municipalities of São Paulo state: The influence of the management of the School Feeding Program and municipal characteristics
}

\author{
Aquisição da agricultura familiar em municípios do \\ estado de São Paulo: a influência da gestão do \\ Programa de Alimentação Escolar e
} características municipais

Vanessa Manfre Garcia de SOUZA ${ }^{1}$ iD 0000-0002-2946-6993

Betzabeth Slater VILLAR ${ }^{1}$ (D) 0000-0003-2511-1770

A B S T R A C T

\section{Objective}

To describe and analyze the implementation aspects of the purchase of food from family farms, according to the management of the School Feeding Program and characteristics of municipalities in the state of São Paulo.

\section{Methods}

A cross-sectional descriptive-analytical study, including 25 municipalities from São Paulo that purchased from family farms for school feeding, where 105 schools were drawn, in 2013, to verify: knowledge of the Law No.11,947/2009, disclosure of the purchasing process, guidance on the management of food, kitchen improvements, variety of food purchased and the use $\geq 30 \%$ of the Program's resources with family farming. Absolute and relative frequencies were analyzed, and Chi-square test and Fisher's exact test were performed $(p<0.05)$.

\footnotetext{
1 Universidade de São Paulo, Faculdade de Saúde Pública, Departamento de Nutrição. Av. Dr. Arnaldo, 715, Cerqueira César, 01246-904, São Paulo, SP, Brasil. Correspondence to: VMG SOUZA. E-mail: <vanessa.manfregs@gmail.com>. Support: Fundação de Amparo à Pesquisa do Estado de São Paulo (Process No.2011/07932-0).

Article based on the dissertation by VMG SOUZA, entitled "Gestão do Programa Nacional de Alimentação Escolar e a implementação da compra da agricultura familiar em municípios de São Paulo”. Universidade de São Paulo; 2017.

How to cite this article

Souza VMG, Villar BS. Acquisition of family farm foods in municipalities of São Paulo state: The influence of the management of the School Feeding Program and municipal characteristics. Rev Nutr. 2019;32:e180083. http://dx.doi.org/10.1590/1678-98 $65201932 \mathrm{e} 180083$
} 


\section{Results}

The knowledge of Law No.11,947/2009 predominated in centralized management $(p=0.010)$ and the disclosure of the purchasing process in school/mixed management $(p=0.010)$; all municipalities of school/mixed management used $\geq 30 \%$ of resources $(p=0.015)$. The disclosure of the purchasing process was more frequent in municipalities with fewer students $(p=0.038)$ and lower Gross Domestic Product $(p=0.020)$; guidance on food management was more frequent in smaller municipalities $(p=0.011)$, with fewer public schools $(p=0.040)$ and lower Gross Domestic Product $(p=0.003)$; the variety of foods was more frequent in smaller municipalities $(p=0.027)$, with fewer students $(p=0.025)$, smaller area $(p=0.025)$ and medium Human Development Index $(p=0.001)$.

\section{Conclusion}

The management of the School Feeding Program and municipal factors can influence the implementation of the purchase of food from family farms.

Keywords: Food and Nutrition Security. Food supply. Local Government. Nutrition Programs and Policies.

\section{RE S U M O}

\section{Objetivo}

Descrever e analisar os aspectos da implementação da compra da agricultura familiar, de acordo com o tipo de gestão do Programa de Alimentação Escolar e características dos municípios do estado de São Paulo.

\section{Métodos}

Estudo transversal descritivo-analítico, com amostra de 25 municípios de São Paulo que compraram da agricultura familiar para a alimentação escolar, onde foram visitadas, em 2013, 105 escolas para verificar: conhecimento da Lei No.11.947/2009, divulgação do processo de compras, orientação sobre manejo dos alimentos ao diretor, melhorias na estrutura da cozinha, variedade de alimentos adquiridos e utilização $\geq 30 \%$ dos recursos do Programa na compra da agricultura familiar. Foram analisadas frequências absolutas e relativas, realizados o Teste Qui-quadrado de Pearson e Teste exato de Fisher $(p<0,05)$.

\section{Resultados}

O conhecimento da Lei No.11.947/2009 foi mais frequente na gestão centralizada $(p=0,010)$ e a divulgação do processo de compras, na escolarizada/mista $(p=0,010)$; todos os municípios de gestão escolarizada/mista utilizaram $\geq 30 \%$ dos recursos $(p=0,015)$. Foi verificada maior frequência de divulgação do processo de compras em municípios com menos alunos $(p=0,038)$ e menor Produto Interno Bruto $(p=0,020)$; maior frequência de orientação sobre manejo dos alimentos em municípios pequenos $(p=0,011)$, com menos escolas públicas $(p=0,040)$, menor Produto Interno Bruto $(p=0,003)$; a variedade de alimentos foi maior em municípios pequenos $(p=0,027)$, com menos alunos $(p=0,025)$, menor área $(p=0,025)$, Índice de Desenvolvimento Humano Municipal médio $(p=0,001)$.

\section{Conclusão}

O tipo de gestão do Programa de Alimentação Escolar e fatores municipais podem influenciar a implementação da compra da agricultura familiar.

Palavras-chave: Segurança Alimentar e Nutricional. Abastecimento de alimentos. Governo Local. Programas e Políticas de Nutrição e Alimentação.

\section{NTRODUCTION}

The Programa Nacional de Alimentação Escolar (PNAE, National School Feeding Program) is one of the largest school feeding programs in the world and a reference for other countries. This program is one of the oldest food and nutrition policy in Brazil, which began in the 1950s, and has since undergone many changes throughout its history $[1,2]$.

A major milestone in changing the PNAE course was the decentralization of the Program, in 1994, when states and municipalities began to receive financial resources from the federal 
government to purchase food and manage the Program [3]. This initiative was fundamental for the promotion of Food and Nutrition Security, achievement of the Human Right to Adequate Food, social participation, and acquisition of food from family farmers [4-6].

The decentralized institutional purchase enabled the acquisition of natural or minimally processed foods, produced locally, which led to the promotion of regional food habits and dynamization of local economy [4,5]. From then on, states and municipalities adopted a management model of financial resources for the acquisition of food for schools. Currently, there are different types of management: a centralized one, in which the municipality or state is responsible for purchasing food; school management, in which schools purchase food; mixed management, in which the municipality or state purchases non-perishable food and schools purchase the perishables; and outsourcing management, in which the municipality or state contract catering services for the provision of meals $[5,7]$.

The Federal Law No.11,947/2009, the legal framework for PNAE, requires, among other important determinations, the compulsory acquisition of food from family farms for PNAE, using, at least, $30 \%$ of all the financial resources from the federal government [8].

A national panorama of the purchases of food from family farms for PNAE, carried out in 2011, showed that of $93.2 \%$ of all Brazilian municipalities, $78.5 \%$ had purchased food from family farms for PNAE. Of these purchases, $44.4 \%$ had used at least $30.0 \%$ of the federal resources for the purchase. The highest percentage of municipalities that purchased food from family farms was the southern region (95.5\%), and the lowest was the midwest region (67.9\%) [9].

In 2010, in the state of São Paulo, of $95.0 \%$ of the state municipalities, $47.0 \%$ had been purchasing food from family farms for PNAE since 2009 [10]. In 2011, the state of São Paulo had the lowest percentage of municipalities that purchased $(66.2 \%)$ from family farms and complied with a minimum of $30.0 \%$ of the federal resources (29.6\%), in the southeast region [9]. In 2013, of a sample of 63 municipalities in the state, $76.2 \%$ had purchased produce from family farms and $46.7 \%$ stated acquiring products using a minimum of $30.0 \%$ of the PNAE resources [11].

When analyzing the data on the 2004-2005 Efficient Management Award for School Feeding, Belik \& Chaim [5] showed that the purchase of food from rural producers is not always associated with the size of the municipality, but, possibly, due to municipality policies that encourage local purchasing.

On the other hand, the national study conducted by Machado et al. [9], in 2011, found that the highest frequency of purchase of food from family farms for PNAE occurred in municipalities with up to 100 thousand inhabitants. In addition, the authors found an association between purchasing food from family farms and the management type of PNAE, such as the highest frequency of purchase was for municipalities with centralized management (80.3\%).

In general, studies on the acquisition of food from family farms for PNAE have analyzed aspects such as the frequency of municipalities that purchased food from family farms, compliance with a minimum of $30 \%$ of the federal resources, public procurement, menus and acquisition challenges [9-18].

However, other aspects on the subject must be evaluated, considering that the acquisition of food for the PNAE is under the responsibility of different players, which depends on the type of management adopted by the executing entity. In this sense, it is important to analyze if aspects such as the involvement of school principals, actions to disclose the acquisition process, training, cooperation with farmers - which can lead to a greater variety of food purchased, for example -, 
and the commitment of managers in adapting and improving the implementation of purchases, vary according to the type of management. In addition, it is necessary to analyze whether contextual factors of the municipality, such as size, demand (number of schools and students) and socioeconomic characteristics can influence the implementation of the purchase of food from family farms.

Thus, the aim of the present article is to describe and analyze the implementation aspects of the purchase of food from family farms, according to the type of management of the School Feeding Program and the characteristics of municipalities in the state of São Paulo.

\section{METHODS}

This is a cross-sectional descriptive-analytical study. The data analyzed are part of a broader research on the association of family farming with the PNAE [4].

The calculation of the sample of municipalities in the state of São Paulo was established by the Simple Random Sampling method without replacement, which considered the following: critical percentile of $95 \%$ of normal distribution, the proportion of municipalities in non-compliance with PNAE - regarding the implementation of the purchase of food from family farms -, the total number of municipalities in the state of São Paulo and the margin of error. Since at the time of the calculation there were no data on the acquisition of food from family farms for the PNAE in the state of São Paulo, a proportion of $10 \%$ of municipalities that had not implemented the purchasing of food was admitted. In addition, a margin of error of $9 \%$, loss of $15 \%$, and a $5 \%$ confidence level were considered, and the result of the calculation of municipalities to compose the broader research sample was 41.

To consider the regional, socio-cultural and agroeconomic characteristics of the municipalities in the sample, the 63 microregions of the state of São Paulo were grouped into six regions (strata) for convenience, considering their boarders with other states and the Atlantic Ocean. Then, the sampling strategy was to draw municipalities proportionally according to the size of the strata.

However, one municipality declined to participate and two were difficult to access, so the broader research sample consisted of 38 municipalities. And, for the present study, the municipalities that had purchased food from family farms for the PNAE in 2012 were selected, totaling 25.

The sample of schools was calculated using the Simple Random Sampling method without replacement, for each of the 41 municipalities of the broader research. As in the municipalities, the primary interest was to assess compliance with the PNAE legislation regarding the purchase from family farms, and it was assumed that school management is influenced by municipal/state management, that is, the school probably follows the instructions of the municipality/state regarding the purchase. It was thus assumed that the proportion of schools that purchased produce from family farms when the municipality had implemented the purchase was $98 \%$. A margin of error of $9 \%$, loss of $20 \%$ and a $5 \%$ significance level were adopted, resulting in the calculation of 259 schools to compose the largest research sample, considering the 41 municipalities.

Among the 259 schools, those that are part of the 25 municipalities that compose the sample of this study were selected, totaling 136 schools. However, 31 schools were lost, of which 20 refused to participate in the survey and 11 were difficult or unsafe access, totaling 105 schools. Therefore, the final sample of this study was composed of 25 municipalities and 105 schools.

In each school, a structured questionnaire was administered to the school leader (principal) and the cook who had been working for the longest time in the area. For this study, the information regarding the percentage of the federal resource used for the purchase from family farmers was 
obtained by a questionnaire administered to the nutritionist responsible for the PNAE of each municipality. Data were collected by nutritionists and nutrition students from January to May 2013.

To verify if the school principal was aware of Law No.11,947/2009 [8] and if the purchasing process from family farms was disclosed to the school community, the following variables were analyzed: the school principal knows the law; disclosure of the purchasing process to the school community.

To verify institutional support from municipal managers for training activities and investment in kitchen improvements to receive the produce from family farmers, and for purchasing a greater variety of foods, the following variables were used: guidance on food management offered to the school leader (guidelines to the school principal on receiving and storing products); kitchen improvements; greater variety of food purchased from family farms. For the variable "greater variety of food purchased from family farms", the mean of the variety of items received in all schools was calculated, obtaining a value of 12.5 items, and the variable was categorized as "yes" (above average) and "no" (below average).

To verify if the municipalities fulfilled the minimum percentage of federal resources for the purchase from family farms, the following variable was used: resources used to purchase from family farmers $\geq 30 \%$. All these variables are dichotomous (yes or no).

For the variable "management type of PNAE", two categories were created: centralized and school/mixed management, since there was no outsourced management. School management and mixed management were grouped into only one category, since the school fully (school management) or partially (mixed management) manages the purchase of food in the two types of management.

For the characterization of the municipalities, secondary data were collected from the free access databases [19-21], from which the variables and respective categories were created, as shown in Table 1. Absolute and relative frequencies were analyzed, and, for the quantitative variables, the median and the minimum and maximum values were calculated.

Table 1. Variables of characterization of municipalities and their categories, according to data from the municipality and source. São Paulo (SP), Brazil, 2010-2013.

\begin{tabular}{|c|c|c|}
\hline Data from the municipality and source & Variable & Category \\
\hline \multirow{2}{*}{ Total population (No. of inhabitants) (IBGE, 2010) } & \multirow{2}{*}{ Size of municipality } & Small: up to 100,000 \\
\hline & & Medium: 100,001 to 500,000 \\
\hline \multirow{2}{*}{ Number of public schools (INEP, 2012) } & \multirow{2}{*}{ Number of public schools } & $\leq 10(\leq$ median $)$ \\
\hline & & >10 (>median) \\
\hline \multirow{2}{*}{ Number of students in state and municipal schools (INEP, 2012) } & \multirow{2}{*}{ Number of students } & $\leq 1,798$ ( $\leq$ median $)$ \\
\hline & & $>1,798$ (>median) \\
\hline \multirow{2}{*}{ Gross Domestic Product per capita (in reais) (IBGE, 2012) } & \multirow{2}{*}{ GDP } & $\leq 17,275.06$ (smedian) \\
\hline & & $>17,275.06$ (>median) \\
\hline \multirow{2}{*}{ Area $\left(\mathrm{km}^{2}\right)$ of the municipality (IBGE, 2010) } & \multirow{2}{*}{ Area } & $<315.27$ (smedian) \\
\hline & & >315.27 (>median) \\
\hline \multirow{2}{*}{ Municipal Human Development Index (IPEA, 2010) } & \multirow{2}{*}{$\mathrm{MHDI}$} & Medium \\
\hline & & High \\
\hline \multirow{2}{*}{$\begin{array}{l}\text { Basic Education Development Index }-4^{\text {th }} / 5^{\text {th }} \text { grade, municipal } \\
\text { school (INEP, 2013) }\end{array}$} & \multirow{2}{*}{ BEDI } & Reached goal \\
\hline & & Did not reach goal \\
\hline
\end{tabular}

Note: BEDI: Basic Education Development Index; GDP: Gross Domestic Product; MHDI: Municipal Development Index; IBGE: Instituto Brasileiro de Geografia e Estatistica (Brazilian Institute of Geography and Statistics) [19]; INEP: Instituto Nacional de Estudos e Pesquisas Educacionais Anísio Teixeira (National Institute of Educational Studies and Research Anísio Teixeira) [21]; IPEA: Instituto de Pesquisa Econômica Aplicada (Institute of Applied Economic Research) [20]. 
Analyses of association were conducted between: (a) variables of characterization of the implementation of the purchase of food from family farms and management type of PNAE; (b) minimum of $30 \%$ of PNAE resources for purchasing from family farmers and management type of PNAE; (c) training and institutional support variables - disclosure of the purchasing process to the school community, guidance on food management offered to the school leader, kitchen improvements, greater variety of food purchased from family farmers, and municipal characteristics.

Pearson's chi-square test and Fisher's exact test (when more than $25 \%$ of the expected frequencies were less than 5 ) were used for the association analyses, considering the level of statistical significance of $5 \%(p<0.05)$. The statistical program Stata (Stata Corporation, College Station, Texas, United States), version 14.0, was used.

All the interviewees signed the free and informed consent term and the study was approved by the Ethics Committee of the School of Public Health of Universidade de São Paulo (USP, São Paulo University) using the Plataforma Brasil (CAAE 54454316.6.0000.5421/Report No.1,548,777).

\section{RE S U L T S}

Among the 25 municipalities of the study, most municipalities were small (88\%), presented a high Municipal Human Development Index (MHDI) (88\%), reached the goal of the Basic Education Development Index (BEDI) for 2013 (54\%) and had the same or below average Gross Domestic Product (GDP) (64\%). In addition, they presented a median of 10 public schools, 1,798 public school students and $315.27 \mathrm{~km}^{2}$ of territorial area, as shown in Table 2.

Regarding the management type of PNAE, 20 (80.0\%) municipalities managed the school feeding program by means of centralized management and $5(20.0 \%)$ by the school or mixed management. Among the 105 schools visited, 83 (79.1\%) were located in municipalities with centralized management and 22 (20.9\%) schools were located in municipalities with school or mixed management.

There was a higher frequency of school leaders who knew Law No.11,947/2009 [8] in municipalities with centralized management $(p=0.010)$. Meanwhile, the frequency of disclosure of the purchasing process was higher in municipalities with school or mixed management $(p=0.010)$, as shown in Table 3.

The percentage frequencies of guidelines on food management to the school leaders and the greater variety of food acquired from family farms were similar between the two management groups. The frequency of school kitchen improvements was reasonably higher in school/mixed management, but no statistically significant differences were found between the two management groups regarding these aspects.

As for the use of PNAE resources with family farming, of the total of 25 municipalities studied, $48 \%$ used at least $30 \%$ of the resources to purchase food from family farmers in 2012 . Among the municipalities with centralized management, the minority used the minimum of the PNAE resources for the purchase of food from family farmers (35\%), while all municipalities with school or mixed management reached the minimum $(p=0.015)$. 
Table 2. Characteristics of the municipalities that purchased food from family farmers for PNAE in 2012. São Paulo (SP), Brazil, 2012.

\begin{tabular}{|c|c|c|}
\hline \multirow{2}{*}{ Variable } & \multicolumn{2}{|c|}{ Municipality } \\
\hline & $(n=25)$ & $\%$ \\
\hline \multicolumn{3}{|l|}{ Size of municipality ${ }^{a}$} \\
\hline Small & 22 & 88.0 \\
\hline Medium & 3 & 12.0 \\
\hline \multicolumn{3}{|l|}{$M H D /^{\mathbf{b}}$} \\
\hline Medium & 3 & 12.0 \\
\hline High & 22 & 88.0 \\
\hline \multicolumn{3}{|l|}{$B E D /^{*}$} \\
\hline Reached goal & 13 & 54.0 \\
\hline Did not reach goal & 11 & 46.0 \\
\hline \multicolumn{3}{|l|}{ GDP per capita ${ }^{\mathrm{d}^{* *}}$} \\
\hline$\leq 21,000$ & 16 & 64.0 \\
\hline$>21,000$ & 9 & 36.0 \\
\hline \multicolumn{3}{|l|}{ Management type of PNAE } \\
\hline Centralized & 20 & 80.0 \\
\hline \multirow[t]{2}{*}{ School or Mixed } & 5 & 20.0 \\
\hline & Median & Min - Max \\
\hline Number of public schools ${ }^{\mathbf{e}}$ & 10 & $2-181$ \\
\hline Number of students ${ }^{f}$ & 1,798 & $441-64,888$ \\
\hline Territorial area $\left(\mathrm{km}^{2}\right)^{\mathrm{a}}$ & 315.27 & $128.18-1,062.70$ \\
\hline
\end{tabular}

Notes: ${ }^{*} n=24 ;{ }^{* *}$ The category values represent the mean of the variable.

${ }^{a}$ Demographic Census [19]; b MHDI: Municipal Human Development Index; medium (0.600-0.699) and high (0.700-0.799) [20]; 'BEDI: Basic Education Development Index $4^{\text {th }} / 5^{\text {th }}$ grade municipal school; goals are individual for each municipality and in agreement with the federal government [21]; ${ }^{\mathbf{d}} \mathrm{GDP}$ : Gross Domestic Product of municipalities per capita (in reais) [19]; ${ }^{\mathbf{e}}$ Number of Basic Education Schools [21]; ${ }^{\text {NNumber }}$ of enrollments in the regular and adult education of state and municipal schools [21].

Table 3. Association between aspects of implementation of the purchase of food from family farms and management type of PNAE. São Paulo (SP), Brazil, 2012-2013.

\begin{tabular}{|c|c|c|c|c|c|}
\hline \multirow{3}{*}{ Variable } & \multicolumn{4}{|c|}{ Management type of PNAE } & \multirow{3}{*}{$p^{*}$} \\
\hline & \multicolumn{2}{|c|}{ Centralized $(n=83)$} & \multicolumn{2}{|c|}{ School or Mixed $(n=22)$} & \\
\hline & $\mathrm{n}$ & $\%$ & $\mathrm{n}$ & $\%$ & \\
\hline \multicolumn{6}{|c|}{ School leader knows the law } \\
\hline Yes & 70 & 84.3 & 13 & 59.1 & 0.010 \\
\hline No & 13 & 15.7 & 9 & 40.9 & \\
\hline \multicolumn{6}{|c|}{ Disclosure of the purchasing process ${ }^{\mathbf{a}}$} \\
\hline Yes & 23 & 31.1 & 13 & 61.9 & 0.010 \\
\hline No & 51 & 68.9 & 8 & 38.1 & \\
\hline \multicolumn{6}{|c|}{ Guidance on food management ${ }^{\mathbf{b}}$} \\
\hline Yes & 29 & 35.8 & 8 & 36.4 & 0.961 \\
\hline No & 52 & 64.2 & 14 & 63.6 & \\
\hline \multicolumn{6}{|c|}{ Kitchen improvement ${ }^{c}$} \\
\hline Yes & 9 & 11.5 & 3 & 14.3 & 0.732 \\
\hline No & 69 & 88.5 & 18 & 85.7 & \\
\hline \multicolumn{6}{|c|}{ Greater variety of food from family farming ${ }^{\mathbf{d}}$} \\
\hline Yes & 16 & 21.9 & 4 & 20.0 & 0.853 \\
\hline No & 57 & 78.1 & 16 & 80.0 & \\
\hline
\end{tabular}

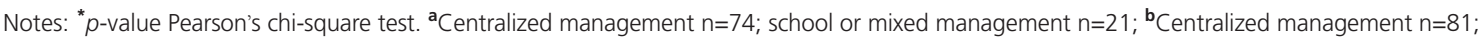
${ }^{c}$ Centralized management $n=78$ and school or mixed management $n=21$; Centralized management $n=73$ and school or mixed management $n=20$. PNAE: Programa Nacional de Alimentação Escolar. 
Table 4 shows the results of the analysis of the association between the implementation aspects of the purchase of food from family farms related to training and the municipality characteristics. The disclosure of the purchasing process by the PNAE nutritionist to the school community was more frequently in municipalities with fewer students ( $p=0.038$ ) and lower $\operatorname{GDP}(p=0.022)$; frequency of guidance on food management offered to the school leader was higher in small municipalities $(p=0.011)$, with fewer public schools $(p=0.040)$ and lower GDP $(p=0.003)$.

As shown in Table 5, school and/or kitchen improvements for the implementation of the purchase of food from family farms, by the municipal government, showed no association with the characteristics of the municipalities. In addition, schools in small municipalities ( $p=0.027$ ), with fewer

Table 4. Association between training activities to the purchasing of food from family farms for the School Feeding Program and characteristics of the municipalities. São Paulo (SP), Brazil, 2012-2013.

\begin{tabular}{|c|c|c|c|c|c|c|c|c|c|c|}
\hline \multirow{3}{*}{$\begin{array}{l}\text { Variable of } \\
\text { municipalities }\end{array}$} & \multicolumn{4}{|c|}{ Disclosure of the purchasing process $(n=95)$} & \multirow{3}{*}{$p^{* *}$} & \multicolumn{4}{|c|}{ Guidance on food management $(n=103)$} & \multirow{3}{*}{$p^{* *}$} \\
\hline & \multicolumn{2}{|c|}{ Yes } & \multicolumn{2}{|c|}{ No } & & \multicolumn{2}{|c|}{ Yes } & \multicolumn{2}{|c|}{ No } & \\
\hline & $n$ & $\%$ & $\mathrm{n}$ & $\%$ & & $\mathrm{n}$ & $\%$ & $\mathrm{n}$ & $\%$ & \\
\hline \multicolumn{11}{|l|}{ Size of municipality ${ }^{a}$} \\
\hline Small & 32 & 39.0 & 50 & 61.0 & 0.569 & 36 & 40.9 & 52 & 59.1 & 0.011 \\
\hline Medium & 4 & 30.8 & 9 & 69.2 & & 1 & 6.7 & 14 & 93.3 & \\
\hline \multicolumn{11}{|l|}{$\begin{array}{l}\text { Number of public } \\
\text { schools } \mathbf{b}^{\mathbf{b}^{*}}\end{array}$} \\
\hline$\leq 10$ & 18 & 46.2 & 21 & 53.8 & 0.166 & 20 & 47.6 & 22 & 52.4 & 0.040 \\
\hline$>10$ & 18 & 32.1 & 38 & 67.9 & & 17 & 27.9 & 44 & 72.1 & \\
\hline \multicolumn{11}{|l|}{$\begin{array}{l}\text { Number of } \\
\text { students }^{* *}\end{array}$} \\
\hline$\leq 1,798$ & 20 & 50.0 & 20 & 50.0 & 0.038 & 17 & 40.5 & 25 & 59.5 & 0.424 \\
\hline$>1,798$ & 16 & 29.1 & 39 & 70.9 & & 20 & 32.3 & 41 & 67.2 & \\
\hline \multicolumn{11}{|l|}{$\begin{array}{l}\text { GDP per capita (in } \\
\text { reais) } \text { d }^{\mathbf{d}}\end{array}$} \\
\hline$\leq 17,275.06$ & 21 & 51.2 & 20 & 48.8 & 0.022 & 23 & 52.3 & 21 & 47.7 & 0.003 \\
\hline$>17,275.06$ & 15 & 27.8 & 39 & 72.2 & & 14 & 23.7 & 45 & 76.3 & \\
\hline \multicolumn{11}{|l|}{$\begin{array}{l}\text { Territorial area } \\
(\mathrm{km})^{2^{\mathbf{a}^{*}}}\end{array}$} \\
\hline$\leq 315.27$ & 16 & 41.0 & 23 & 59.0 & 0.610 & 15 & 34.9 & 28 & 65.1 & 0.852 \\
\hline$>315.27$ & 20 & 35.7 & 36 & 64.3 & & 22 & 36.7 & 38 & 63.3 & \\
\hline \multicolumn{11}{|l|}{$M H D / e$} \\
\hline Medium & 5 & 38.5 & 8 & 61.5 & 0.964 & 4 & 40.8 & 9 & 69.2 & 0.681 \\
\hline High & 31 & 37.8 & 51 & 62.2 & & 33 & 36.7 & 57 & 63.3 & \\
\hline \multicolumn{11}{|l|}{$B E D f^{f * * *}$} \\
\hline Reached goal & 16 & 31.4 & 35 & 68.6 & 0.109 & 24 & 44.4 & 30 & 55.6 & 0.067 \\
\hline Did not reach goal & 20 & 47.6 & 22 & 52.4 & & 12 & 26.7 & 33 & 73.3 & \\
\hline
\end{tabular}

Notes: ${ }^{*}$ The category values represent the median of the variable; ${ }^{* *} p$-value Pearson's chi-square test; ${ }^{* * *} n=93$.

${ }^{a}$ Demographic Census [19]; ${ }^{\mathbf{b}}$ Number of Basic Education Schools [21]; 'Number of enrollments in the regular and adult education of state and municipal schools [21]; ${ }^{d}$ GDP: Gross Domestic Product of municipalities per capita (in reais) [19]; ${ }^{\mathrm{MHDI}}$ : Municipal Human Development Index; medium (0.600-0.699) and high (0.700-0.799) [20]; ${ }^{\mathrm{B} E D D I}$ : Basic Education Development Index $4^{\text {th }} / 5^{\text {th }}$ grade municipal school; goals are individual for each municipality and in agreement with the federal government [21]. 
students $(p=0.025)$, smaller territorial area $(p=0.025)$ and medium MHDI $(p=0.001)$ received a greater variety of food from family farms.

Table 5. Association between institutional support actions to the purchasing of food from family farms for the School Feeding Program and characteristics of the municipalities. São Paulo (SP), Brazil, 2012-2013.

\begin{tabular}{|c|c|c|c|c|c|c|c|c|c|c|}
\hline \multirow{3}{*}{ Variables of municipalities } & \multicolumn{5}{|c|}{ Kitchen improvement $(n=99)$} & \multicolumn{5}{|c|}{ Greater variety of food from family farming $(n=93)$} \\
\hline & \multicolumn{2}{|c|}{ Yes } & \multicolumn{2}{|c|}{ No } & \multirow{2}{*}{$p^{* *}$} & \multicolumn{2}{|c|}{ Yes } & \multicolumn{2}{|c|}{ No } & \multirow{2}{*}{$p^{* *}$} \\
\hline & $\mathrm{n}$ & $\%$ & $\mathrm{n}$ & $\%$ & & $\mathrm{n}$ & $\%$ & $\mathrm{n}$ & $\%$ & \\
\hline \multicolumn{11}{|l|}{ Size of municipality ${ }^{a}$} \\
\hline Small & 12 & 14.3 & 72 & 85.7 & 0.118 & 20 & 25.6 & 58 & 74.4 & 0.027 \\
\hline Medium & 0 & - & 15 & 100.0 & & 0 & - & 15 & 100.0 & \\
\hline \multicolumn{11}{|l|}{ Number of public schools $\mathbf{b}^{\mathbf{*}}$} \\
\hline$\leq 10$ & 8 & 19.5 & 33 & 80.5 & 0.058 & 9 & 23.7 & 29 & 76.3 & 0.671 \\
\hline$>10$ & 4 & 6.9 & 54 & 93.1 & & 11 & 20.0 & 44 & 80.0 & \\
\hline \multicolumn{11}{|l|}{ Number of students ${ }^{*}$} \\
\hline$\leq 1,798$ & 8 & 19.1 & 34 & 80.9 & 0.071 & 13 & 32.5 & 27 & 67.5 & 0.025 \\
\hline$>1,798$ & 4 & 7.0 & 53 & 93 & & 7 & 13.2 & 46 & 86.8 & \\
\hline \multicolumn{11}{|l|}{ GDP per capita (in reais) $\mathbf{d}^{\mathbf{d}^{*}}$} \\
\hline$\leq 17,275.06$ & 8 & 18.6 & 35 & 81.4 & 0.083 & 11 & 28.2 & 28 & 71.8 & 0.181 \\
\hline$>17,275.06$ & 4 & 7.1 & 52 & 92.9 & & 9 & 16.7 & 45 & 83.3 & \\
\hline \multicolumn{11}{|l|}{ Territorial area $\left(\mathrm{km}^{2}\right)^{\mathrm{a}^{*}}$} \\
\hline$\leq 315.27$ & 6 & 14.6 & 35 & 85.4 & 0.523 & 13 & 32.5 & 27 & 67.5 & 0.025 \\
\hline$>315.27$ & 6 & 10.3 & 52 & 89.7 & & 7 & 13.2 & 46 & 86.8 & \\
\hline \multicolumn{11}{|l|}{$M H D l^{e}$} \\
\hline Medium & 1 & 7.7 & 12 & 92.3 & 0.604 & 7 & 58.3 & 5 & 41.7 & 0.001 \\
\hline High & 11 & 12.8 & 75 & 87.2 & & 13 & 16.1 & 68 & 83.9 & \\
\hline \multicolumn{11}{|l|}{$B E D f^{f * * *}$} \\
\hline Reached goal & 7 & 8.9 & 44 & 91.1 & 0.458 & 9 & 18.7 & 39 & 81.3 & 0.404 \\
\hline Did not reach goal & 4 & 13.7 & 41 & 86.3 & & 11 & 26.2 & 31 & 73.8 & \\
\hline
\end{tabular}

Notes: ${ }^{*}$ The category values represent the median of the variable; ${ }^{* *} p$-value Pearson's chi-square test; ${ }^{* * *} n=93$.

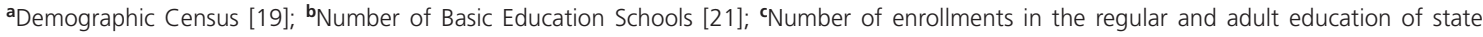
and municipal schools [21]; ${ }^{\mathbf{d}}$ GDP: Gross Domestic Product of municipalities per capita (in reais) [19]; ${ }^{\mathbf{e}} \mathrm{MHDI}$ : Municipal Human Development Index; medium (0.600-0.699) and high (0.700-0.799) [20]; ${ }_{\mathrm{BEDDI}}$ : Basic Education Development Index $4^{\text {th }} / 5^{\text {th }}$ grade municipal school; goals are individual for each municipality and in agreement with the federal government [21].

\section{I SCUSSIO N}

This study observed that some aspects considered favorable for the success of the implementation of the purchase of food from family farms for the PNAE were predominant in centralized management (knowledge of Law No.11,947/2009) and school or mixed management (disclosure of the purchasing process and use of more than 30\% of the PNAE resources for purchases from family farmers), and these aspects were associated with management. 
In schools in which the management of PNAE was centralized, there was a higher frequency of school leaders who knew Law No.11,947/2009 [8] and an association was observed. School principals, in all management types of PNAE, must know the law, but the frequency was expected to be greater in school or mixed management because the school leaders participate totally or partially in the acquisition of food.

One possible reason for the lack of knowledge of Law No.11,947/2009 [8] might be because school employees are assigned to the task of managing the purchase of food and, therefore, the school principal does not participate in the process. It should be noted that the federal government promotes means to inform and train PNAE players, among them, the Programa Formação pela Escola (School Training Program) through distance education [22].

The result of the highest frequency of the disclosure of the purchasing process in schools with school or mixed management was expected, since in this kind of management the schools are responsible for the acquisition of food and must be aware of the entire process.

This result suggests that in school management or shared management between municipalities and schools, school leaders should be more cooperative and closer to the school community. In this sense, there is a commitment to disseminate Law No.11,947 [8] and the purchasing process from family farmers in schools.

According to Schwartzman et al. [4], poor kitchen facilities are still an unfavorable aspect for the implementation of the purchase of food from family farms for PNAE. Although no association was found, school kitchen improvements were more frequent in school/mixed management, which again means the proximity of the municipal managers with schools.

However, studies found municipalities with centralized management, between 2010 and 2011, both in the state of São Paulo, which were successful purchasing produce from family farmers. The two municipalities, Tambaú and São Bernardo do Campo, made adaptations and adjustments to comply with Law No.11,947 [8], such as kitchen improvements and the training of cooks by a nutritionist. In addition, the proximity and the dialogue of the public sphere with farmers and their organizations is imperative $[15,16]$.

The proportion of schools that received a greater variety of food from family farmers was similar among the different types of management, although no association was found.

The present study showed that the minimum of 30\% of federal resources for purchasing from family farmers is associated with the management type of PNAE $(p=0.015)$, and all municipalities with school or mixed management reached $30 \%$, while a minority (35\%) of centralized management achieved the goal.

This result suggests that decentralized acquisition of food presupposes greater proximity and cooperation of the schools with farmers. In addition, a higher percentage of schools that had disclosed the purchasing process from family farmers was observed for school or mixed management.

Regarding the municipality characteristics, the disclosure of the purchasing process to the school community by the nutritionist was more frequent in municipalities with fewer students and lower GDP. These results suggest that in municipalities with fewer students, generally smaller municipalities, disclosure should occur broadly, considering the greater proximity between managers and schools. It should be noted that municipalities with a larger number of students should have more nutritionists working in the PNAE, according to the parameters of the Resolution of the Federal 
Council of Nutritionists No.465/2010, and thus, perhaps, nutritionists could develop tasks such as disclosing the purchasing process, among many other assignments [23].

To foster the training of all the players involved in the purchasing process, educational actions involving the community, as well as the schools, and intersectoral actions are necessary [24].

The data from the present study showed that the training of PNAE players, such as guidance on food management to the school principal, predominated in small municipalities. As for the disclosure of the purchasing process, the explanation for this result may be the greater proximity of the PNAE social players in smaller municipalities.

It is interesting to note that the size of the municipalities was associated with all aspects of institutional support, except for kitchen improvements, which was not associated with municipal characteristics.

Among these aspects, the greatest variety of food received from family farmers by the schools was associated with size $(p=0.027)$, number of students $(p=0.025)$, territorial area $(p=0.025)$ and MHDI $(p=0.001)$ of municipalities.

According to the literature, the proximity of the small municipality to the local producer, that is, the short trading cycle, can favor the delivery of a greater variety of fresh and good quality food items. In addition, there is a closer relationship between the players involved in the purchase of food and local farmers, often personal relationships and not only institutional ones [16,25-27].

In this sense, Balestrin [26] found that, in small municipalities, farmers are challenged to produce new products by increasing the variety of food provided for school meals.

Teo et al. [28] observed in their study with five small municipalities, in Santa Catarina, that the social players of the PNAE (education managers, nutritionists, cooks and farmers) recognized Law No.11,947/2009 [8] as an incentive for family farming, support for local development, and improvement of school meal quality. In addition, education leaders stated that the regulations brought them closer to the management of PNAE. In these small municipalities, local public authorities promoted actions to encourage the implementation of Law No.11,947/2009 [8] to disseminate information on the acquisition of produce from family farmers for PNAE, such as guidelines on food management.

On the other hand, large municipalities may have difficulties with the supply logistics of schools, due to the greater number of delivery places, transportation difficulties and storage of products, for example $[17,29]$.

In addition, Balestrin [26] states that in small municipalities, the shorter distance and assurance of the dissemination of public procurement enable farmers to be more aware how food sales to the PNAE occur and seek better strategies to sell their produce.

Irrespective of the size of the municipality, the support and commitment of local public authorities and municipal management are fundamental for the success of the implementation of the purchase of food from family farms for PNAE $[16,28,30]$.

Finally, it is important to emphasize the importance of the institutional purchase from family farmers for the promotion of Food and Nutrition Security and Human Right to Adequate Food of the students as well as the improvement of the living conditions of the farmers, since it stimulates the production of food and generates income for families [4,15,28,31,32]. 
The limitation of the study was the loss of 31 schools (22.8\%) and, therefore, inferences should be made with caution, considering the possibility of extrapolating the results to all the schools of the municipalities evaluated.

\section{CONCLUSION}

The compulsory purchase from family farmers for PNAE represents one of the greatest advances of the program over the last decade. The political will, the interest of managers and cooperation among the social players involved in the execution of the program are crucial for the involvement of family farmers with school feeding to be successful.

Finally, the study showed that the management type of PNAE and characteristics such as size of the municipality (in terms of population and area), number of students and public schools, MHDI and GDP can influence the implementation of the purchase of food from family farms for school food.

In addition, there seems to be no better or ideal type of management, and each state and municipality must adopt the best management model according to their context, social, political, economic, demographic and territorial characteristics.

\section{CONTRIBUTORS}

VMG SOUZA contributed to the conception of the study, bibliographic review, data analysis and writing of the manuscript. BS VILLAR contributed to the design of the study and revision of the manuscript.

\section{ACKNOWLEDGEMENTS}

The study was funded by the Coordenação de Aperfeiçoamento de Pessoal de Nivel Superior (CAPES, Coordination for the Improvement of Higher Education Personnel).

\section{REFERE NCES}

1. Cesar JT, Valentim EA, Almeida CCB, Schieferdecker MEM, Schmidt ST. Alimentação escolar no Brasil e Estados Unidos: uma revisão integrativa. Ciênc Saúde Coletiva. 2018;23(3):991-1007. http://dx.doi. org/10.1590/1413-81232018233.01582016

2. Fundo Nacional de Desenvolvimento da Educação. Referência mundial, o Programa Nacional de Alimentação Escolar completa 62 anos de conquistas. Brasília: FNDE; 2017 [citado 2017 maio 10]. Disponível em: http:// www.fnde.gov.br/fnde/sala-de-imprensa/noticias/item/10517-refer\%C3\%AAncia-mundial,-o-programanacional-de-alimenta\%C3\%A7\%C3\%A3o-escolar-completa-62-anos-de-conquistas

3. Câmara dos Deputados (Brasil). Lei №8.913, de 12 de julho de 1994. Dispõe sobre a municipalização da merenda escolar. Diário Oficial da União. 1994;Seção1:p.10521.

4. Schwartzman F, Rodriguez Mora CA, Bogus CM, Villar BS. Background and elements of the linkage between the Brazilian school feeding program and family farming. Cad Saúde Pública. 2017;33(12):e00099816. http://dx.doi.org/10.1590/0102-311x00099816

5. Belik W, Chaim NB. O programa nacional de alimentação escolar e a gestão municipal: eficiência administrativa, controle social e desenvolvimento local. Rev Nutr. 2009;22(5):595-607. http://dx.doi.org/10.1590/S1415-52 732009000500001 
6. Siqueira RL, Cotta RMM, Ribeiro RCL, Sperandio N, Priore SE. Análise da incorporação da perspectiva do direito humano à alimentação adequada no desenho institucional do programa nacional de alimentação escolar. Ciênc Saúde Coletiva. 2014;19(1):301-10. http://dx.doi.org/10.1590/1413-81232014191.2114

7. Machado PMO, Machado MS, Schmitz BAS, Corso ACT, González-Chica DA, Vasconcelos FAG. Caracterização do Programa Nacional de Alimentação Escolar no Estado de Santa Catarina. Rev Nutr. 2013;26(6):715-25. http://dx.doi.org/10.1590/S1415-52732013000600010

8. Presidência da República (Brasil). Lei N¹1.947, de 16 de junho de 2009. Dispõe sobre o atendimento da alimentação escolar e do Programa Dinheiro Direto na Escola aos alunos da educação básica; altera as Leis nos 10.880, de 9 de junho de 2004, 11.273, de 6 de fevereiro de 2006, 11.507, de 20 de julho de 2007; revoga dispositivos da Medida Provisória no 2.178-36, de 24 de agosto de 2001, e a Lei No.8.913, de 12 de julho de 1994; e dá outras providências. Diário Oficial da União. 2009;p.2.

9. Machado PMO, Schmitz BAS, González-Chica DA, Corso ACT, Vasconcelos FAG, Gabriel CG. Compra de alimentos da agricultura familiar pelo Programa Nacional de Alimentação Escolar (PNAE): estudo transversal com o universo de municípios brasileiros. Ciênc Saúde Coletiva. 2018;23(12):4153-64. http://dx.doi. org/10.1590/1413-812320182311.28012016

10. Villar BS, Schwartzman F, Januario BL, Ramos JF. Situação dos municípios do estado de São Paulo com relação à compra direta de produtos da agricultura familiar para o Programa Nacional de Alimentação Escolar (PNAE). Rev Bras Epidemiol.2013;16(1):223-6.

11. Bandoni DH, Stedefeldt E, Amorim ALB, Gonçalves HVB, Rosso VV. Desafios da regulação sanitária para a segurança dos alimentos adquiridos da agricultura familiar para a alimentação escolar. Visa em Debate. 2014;2(4):107-14.

12. Hanashiro MM, Matsuura FFCAU, Lima IA, Beriam LOS, Maddarena EF, Minitti Af, et al. Transferência de tecnologias apropriadas para a agricultura familiar: uma experiência de ação integrada no estado de São Paulo. Cad Ciênc Tecnol. 2011;28(1):51-80.

13. Baccarin JC, Triches RM, Teo CRPA, Silva DBP. Indicadores de avaliação das compras da agricultura familiar para alimentação escolar no Paraná, Santa Catarina e São Paulo. Rev Econ Sociol Rural. 2017;55(01):103-22. http://dx.doi.org/10.1590/1234-56781806-94790550106

14. Amorim ALB, Rosso VV, Bandoni DH. Acquisition of family farm foods for school meals: Analysis of public procurements within rural family farming published by the cities of São Paulo state. Rev Nutr. 2016;29(2):297-306. http://dx.doi.org/10.1590/1678-98652016000200012

15. Chaim N, Belik W. São Bernardo do Campo: atuação pioneira em favor da agricultura familiar. In: Corá MAJ, Belik W. Projeto Nutre SP: análise da inclusão da agricultura familiar na alimentação escolar no estado de São Paulo. Brasília: Ministério do Desenvolvimento Agrário; 2012.

16. Vannuchi LVB, Reinach S. Estudo de caso de sucesso na aquisição de produtos da agricultura familiar para alimentação escolar: município de Tambaú - SP. In: Corá MAJ, Belik W. Projeto Nutre SP: análise da inclusão da agricultura familiar na alimentação escolar no estado de São Paulo. Brasília: Ministério do Desenvolvimento Agrário; 2012.

17. Siliprandi E, Belik W. A agricultura familiar e o atendimento à demanda institucional das grandes cidades. In: Corá MAJ, Belik W. Projeto Nutre SP: análise da inclusão da agricultura familiar na alimentação escolar no estado de São Paulo. Brasília: Ministério do Desenvolvimento Agrário; 2012.

18. Ferigollo D, Kirsten VR, Heckler D, Figueredo OAT, Perez-Cassarino J, Triches RM. Aquisição de produtos da agricultura familiar para alimentação escolar em municípios do Rio Grande do Sul. Rev Saúde Pública. 2017;51(6):1-10. http://dx.doi.org/10.1590/\$1518-8787.2017051006648

19. Instituto Brasileiro de Geografia e Estatística. Nota técnica: estimativas da população dos municípios brasileiros com data de referência em $1^{\circ}$ de julho de 2014. Rio de Janeiro: IBGE; 2014.

20. Instituto de Pesquisa Econômica Aplicada. Atlas do Desenvolvimento Humano no Brasil: ranking todo o Brasil (2010) - Municipal; 2010 [citado 5 jul 2017]. Disponível em: http://www.atlasbrasil.org.br/2013/pt/ranking

21. Instituto Nacional de Estudos e Pesquisas Educacionais Anísio Teixeira. Resultados e metas: município, 2013. Brasília: INEP; 2013.

22. Fundo Nacional de Desenvolvimento da Educação. Programas: formação pela escola. Brasília: FNDE; 2018 [citado 24 out 2018]. Disponível em: http://www.fnde.gov.br/programas/formacao-pela-escola 
23. Conselho Federal de Nutricionistas. Resolução CFN N465, de 23 de agosto de 2010. Dispõe sobre as atribuições do Nutricionista, estabelece parâmetros numéricos mínimos de referência no âmbito do Programa de Alimentação Escolar (PAE) e dá outras providências. Diário Oficial da União. 2010;Seção1:p.118-19.

24. Melo MNT, Sá RMPF, Melo Filho DA. Sustentabilidade de um programa de alimentação escolar bem-sucedido: estudo de caso no Nordeste do Brasil. Ciênc Saúde Coletiva. 2016:21(6):1899-908. http://dx.doi. org/10.1590/1413-81232015216.08752016

25. Abreu KDR. A implementação do Programa Nacional de Alimentação Escolar (PNAE) em municípios de pequeno porte: implicações práticas e teóricas [Dissertação]. São Paulo: Escola de Administração de Empresas de São Paulo, Fundação Getulio Vargas; 2014.

26. Balestrin ELB. As estratégias de inserção dos agricultores familiares no Programa de Alimentação Escolar de Capitão Leônidas Marques [Dissertação]. Pato Branco: Universidade Tecnológica Federal do Paraná; 2014.

27. Triches RM, Kilian L. Papel dos atores sociais na aquisição de produtos da agricultura familiar para alimentação escolar em municípios paranaenses. Redes. 2016;21(3):159-79. http://dx.doi.org/10.17058/ redes.v21i3.7055

28. Teo CRPA, Motter AF, Barbosa LP, Dacroce M, Pagliarini G. Articulação entre agricultura familiar e alimentação escolar em municípios de pequeno porte. Rev Geo Agrária. 2016;11(24):175-99.

29. Costa BAL, Amorim Junior PCG, Silva MG. As cooperativas de agricultura familiar e o mercado de compras governamentais em Minas Gerais. Rev Econ Sociol Rural. 2015;53(01):109-26.

30. Gabriel CG, Calvo MCM, Ostermann RM, Vasconcelos FAG. Proposta e aplicabilidade de modelo para avaliação da gestão municipal do Programa Nacional de Alimentação Escolar. Cad Saúde Pública. 2014;30(8):1731-44. http://dx.doi.org/10.1590/0102-311X00033913

31. Schwartzman F. Vinculação do Programa Nacional de Alimentação Escolar (PNAE) com a agricultura familiar: caracterização da venda direta e das mudanças para os agricultores familiares em municípios do estado de São Paulo [Doutorado]. São Paulo: Universidade de São Paulo; 2015.

32. Triches RM, Schneider S. Alimentação escolar e agricultura familiar: reconectando o consumo à produção. Saúde Soc. 2010;19(4):933-45. http://dx.doi.org/10.1590/S0104-12902010000400019 